\title{
Agricultural Workers: Field Research with an Imagined Community that is Mobile and Hard-to-Reach
}

\author{
Keith V. Bletzer*
}

School of Human Evolution and Social Change, Arizona State University, Tempe, Arizona, USA

\begin{abstract}
Fieldwork strategies are showing increasing concern about contributing something of value to the local community, where one has conducted research. This concern for payback has centered on countermanding the obvious, visible benefits to individual researchers, or a research team, than whatever contributions have gone to the community, which are likely to be much less visible. Alternatives to direct community contributions include sharing expertise with those that provide basic services and advocates who work on behalf of the population. Research with farm workers requires shifts in field techniques that take into account continuing geographic mobility, irregular employment, and a precarious economic situation experienced by the study population. This article describes the author's experience in conducting long-term ethnography among farm workers across multiple sites along the eastern United States. Strategies of fieldwork among this mobile and hard-to-reach population are compared against standards of fieldwork that have been articulated in four classic monographs from the social sciences. An overview of findings from research among agricultural workers is offered as evidence of the appropriateness of reliance on emerging field strategies that consider the safety and well-being of the population, simultaneous with selecting what eventually become valid and reliable techniques of data collection.
\end{abstract}

Keywords: Participatory research, agricultural labor, social adversity, southeastern United States.

\section{INTRODUCTION}

Health research with a migrant population challenges the investigator in unique ways. First and foremost, the population is not stationary in one locale for any lengthy period of time, given the need to travel to new locales to seek employment. This affects sampling and the choices of topics for investigation. Second, portions of the population that remain behind might not be currently working in farm labor or no longer work in agriculture and thus be inappropriate for study, if the focus of the investigation is an aspect of migratory experience or some issue that currently affects farm labor. Conversely, that portion of the population that remains behind at one point in time can return to migratory travel, or they may move to a new community, where they re-settle.

The common experience for each of us in these mini-hottopic selections has been working with immigrants from Latin America and the Caribbean. For many newcomers to the United States whose origins generally are northern countries of Central America and several islands of the Caribbean, the main means of livelihood has been some form of agricultural labor. Since each author will introduce his research interest, which for all of us has become a passion, I will devote my space in this article to comparing my field research against the backdrop of classic field studies in the social sciences. These studies provide a grounded view of general standards for research. Following this, I will provide selective findings from long-term ethnography.

*Address correspondence to this author at the School of Human Evolution and Social Change, Arizona State University, Tempe, Arizona 85287-2402, USA; Tel: 520-229-2785; E-mail: keith.bletzer@asu.edu
For more than a decade I have worked with migrants. In each endeavor, to whatever part of the country that it took me, my main responsibility was ethnographic research. One research project was an epidemiological research-education program for workers at risk for HIV that ran for four years and covered six states bordering the Atlantic Ocean (USA), where I was part of a university team, and another was a two-year field project that took me back to these states, plus one additional state, where I continued the field research, while collecting life story interviews. One agricultural town served as the home-base for these two projects. Before these endeavors, I spent three years in the Midwest (USA) developing, coordinating and assessing a migrant-camp HIV education program, where I participated in quarterly program reviews and planning with similar coordinators from four other Midwestern states. After all this, while living along the US-Mexico border, I briefly returned to agricultural areas in the Southeast and Midwest as well as brief visits to agricultural areas in the Southwest and Northwest. Through that later experience and since that time, I have worked intermittently with farm workers, migrant service providers and advocates by giving presentations at regional health educationpracticum conferences. This, then, is the means by which I have used what I gained from participatory research to improve the living and working conditions among agricultural workers. If some means of benefiting workers was not builtin to the project, which it was for the prevention-education project, I have sought to reach many more than those with whom I had direct field contact by providing research expertise and field knowledge to advocates for, and the frontline workers in, migrant services.

Ethnography is well-suited to investigations where the information ("data") is not easily accessed by other methodologies. It requires long-term engagement with a population 
of interest, systematic data collection generally through qualitative rather than quantitative methods, and the immersion of the researcher into daily activities of the community $[1,2]$. When the population is not established in residential or occupational space, that is, its people move about, a researcher has to accommodate, to the extent possible, to move with the people, and/or develop alternative methods that will assure acquisition of reliable and valid data. A long-term ethnography is one of these alternatives, which can be enhanced by sampling more than one site.

Long-term single-visit studies are distinct from those where a field researcher develops a continuing relationship with a particular community or "people" and returns, repeatedly, over the years, after completing the initial study. We note that, until recent decades, the North American classics in long-term single-visit ethnography were written by male researchers. If we look to the established researchers who conducted continuing multiple-return field research, however, the list would include female and male researchers whose ethnographies also became social science classics. Like the single-visit studies based on and written about large urban areas in the United States (including those I review below), these multiple-return studies generally were conducted outside this country, usually in a rural area, among a people whose language was not English, by utilizing field methodologies that were drawn from anthropology and sociology. We can call the former first-visit extended fieldwork and the latter continuing multiple-return investigation. Both styles characterize aspects of my research with migrants.

\section{DRAWING UPON THE CLASSIC ETHNOGRAPHIES}

The better-known first-visit long-term ethnographies that have been conducted in this country in social science, interestingly, have been conducted within metropolitan rather than rural areas. Through popularity among the general public and applicability to teaching as well-written and conceptually strong examples of exemplary field research, not to mention immensely entertaining reading, several long-term ethnographies have been elevated to the status of classics in the social sciences. The fieldworker's graduate training for each of these was a combination of anthropology and sociology. Based on publications separated by at least a decade, I selected four better-known North American classic studies to serve as a comparative standard for my research: Street Corner Society by William Foote Whyte (first edition 1943, fourth edition 1993) focusing on an Italian neighborhood in Boston [3] , Tally's Corner by Elliot Liebow (first edition 1967) focusing an African American neighborhood in northwestern Washington, DC [4]; A Place on the Corner by Elijah Anderson (first edition 1978, second edition 2003) focusing on an African American neighborhood in south Chicago [5], and In Search of Respect by Philippe Bourgois (first edition 1995, second edition 2003) focusing on Spanish Harlem in The Bronx, New York City [6]. To attest to their status as classics, each became available through revised and several reprinted editions, as well as paperback editions.

Since dates of fieldwork range from the 1930s to the 1990 s, we might expect changes in society to have influenced the style of presentation of research findings, to a greater degree than the manner in which the fieldwork was conducted. If we consider, however, that the instrument of data collection is the Individual Investigator for most studies in anthropology and sociology, we might look for variations in the way the fieldwork was conducted in the field.

For the four classic first-visit extended studies that I enumerated above, the ethnography (as research) was an almost daily endeavor in the field, and the ethnography (as writing) included generous field notes and reported speech to enliven findings. The recent study by Bourgois, for example, incorporates extensive passages from men that formed the primary participants in his research, which often appear as extended and indented (blocked) quotations. Remarkably, he is the only researcher to use field tapes, wherein he received permission to tape ongoing talk in the street and in the Game Room (his base site). Each of the four authors describes his field methods, which mostly included data collection through 'participant-observation' in local settings as well as informant networks or personal living spaces, detailed in an appendix (Whyte, Liebow), or in a preface and in the first chapter (Anderson: no appendix) or introduction on theory and methods and first chapter on local setting (Bourgois: no appendix).

The first chapter in each research monograph emphasizes the illustrative tale of an atypical encounter. Anderson met Calvin once and never saw him again, for example, and Bourgois tells the story of unintentionally "disrespecting" the local drug boss, thus endangering himself and his study. After each writer builds the literary tension, the initial misstep is followed by the common Tale of Encounter with the main informant. Anderson met "Herman" four months into his study; Bourgois met "Primo" 4-6 months into his study; Whyte met "Doc" 6-8 months into his study; but Liebow met "Tally" a mere two days after arrival in the field site.

What are the practices these field researchers report and what is their relationship to the people that formed the sample as well as the population they studied? Early introductory texts in anthropology refer to this process as moving from "stranger-hood to acquaintance," which takes place as the fieldworker obtains a general expertise in knowledge about the people under study and moves closer to achieving professional status for having completed the fieldwork $[1,2,7$, 8]. Below, I summarize aspects of the four studies that I selected and compare these against the way that I conducted my research among migrant workers.

\section{SIMILARITIES AND DIFFERENCES}

First, I consider six areas that demonstrate techniques that act as tactics for participatory immersion into the field setting, before examining the author's description of the relationship between fieldworker and the individuals portrayed as informants. These six areas focus on the inter-relationship between the fieldwork and those who form the core group of investigation.

\section{A. Provided Transportation}

Field researchers in urban areas and rural areas have generally been involved, one way or another, in transporting study participants. Within days of his arrival in the field site, Liebow was driving the man who became his main informant, Tally, to court, which he reports as his first action in the field. When requested late in his fieldwork, Anderson drove one of his informants to shop for his wife. Bourgois 
walked and/or rode the subway with informants and rode a bicycle for self-exercise. Whyte is silent on whether he transported his informants or means of transportation he used; he does not report having a vehicle while living in his field site.

While I was working in the farming community for the epidemiological-education study, the university provided a van "to transport clients" during project hours. I also had my own car. If the van was in use during project hours, I occasionally took respondents back home in my car and occasionally I used it to transport men or women of the small town during times the project was closed. As we opened scheduled field stations in different states, I drove the van from one site to another for sequential use within distinct agricultural seasons. I would stay a few days to monitor and supervise local project staff and check their data collection through a survey, before returning to the base-site via airline. Later, I returned to each site to transport the van to the next station. For the second and third years, I had use of the same van each summer for a two-month field study, where I traveled among several states along the east coast of the United States. Since I removed the back seats (left in the base station) to provide space for sleeping on-the-road, there was limited space and no seat belts to transport people whom I met in my travels.

When I shifted to my own research and collected life stories, I used my own vehicle for taping life story interviews, usually at one of three quiet but visibly public locations in the farm town that served as my home-base. Where people were living was often too noisy to tape. While traveling to other states for this two-year study, I rented a vehicle, rather than travel by airline; in this vehicle I occasionally transported people short distances. I sometimes rode with staff as they transported men to AA meetings, or I myself transported these men to these meetings. When not staying with field contacts, a practice similar to that of Miriam Wells [9], another researcher of agricultural workers, I slept in the rental vehicle, which was something that she does not report. Occasionally researchers of farm workers have lived in the camps, such as the ambitious multi-site study organized and supervised by Friedland and Nelkin [10], where several students lived and worked with farm workers in the state of New York, and dissertation research by Monica Lucille Heppel [11], where she lived and worked with migrant workers in Virginia and Florida.

\section{B. Sports}

Across the four classic studies, participation in competitive physical activity wanes over time. Whyte occasionally played baseball and bowled with the men. Liebow, Anderson and Bourgois on the other hand are silent on participation in locally-sanctioned sports. Liebow went to local pool rooms but did not play; he states that he had a personal rule during his study to not gamble. Anderson reports he once armwrestled an informant; after beating him the first time, he let the other man beat him with the opposite arm. Bourgois reports that he once took an 11-year-old boy to a local library. All four appear to have spent more time "hanging-out" rather than any participation in sports.

Volleyball was a common pastime in some areas where I visited migrant labor camps and I willingly joined the work- ers a few times, when invited to play. Although soccer was frequent, I spent my time on the sidelines, enjoying impromptu games. Since I visited pool rooms in several sites to which I traveled, I watched the men and women play while interacting intermittently with people who were present. In the home-base, if I was invited, I occasionally played pool, but not for money. For those who were inclined, the bets ranged from a few quarters to a few dollars and typically stopped at five dollars. Those whom I played were newcomers to town or those whom I knew from contacts in the street. The "grand players," who had a reputation of finesse and skill, I never played; rather, I enjoyed watching their games. Although I suspect other researchers have played sports with migrants, during research, to my knowledge no one reports their experience.

\section{Swearing}

Inclusion of cursing increases in the recent monographs, from mild curse-words to heavier swearing with greater frequency in the later studies. Whyte mentions that cursing occurs but it does not appear in the reported speech of his informants, except for infrequent contact with certain social types (like crap-game operator). He refers to one incident where he cursed and was quickly warned to not repeat the swearing. Anderson reports that his site (Jelly's) created a rule against cursing; he places it sparingly in the reported speech of his main informant, Herman, and other field contacts. Liebow through reported speech includes occasional cursing by nameless individuals but never primary informants; once he uses an example of his cursing in the reported speech of himself in an appendix. Bourgois incorporates reported speech for himself and several informants throughout passages in the text, where swearing is included as a realistic portrayal. As mentioned, he taped the "real speech" of the street in his field site.

Swearing was something that I observed while growingup (neighborhood and family), but not a practice that I acquired. Somehow I learned to stifle inclinations that stemmed from my early exposure to rough language. While doing fieldwork among migrants, I heard variations on swearing in both English and Spanish, but I was never pressed by local people to use this form of casual register. Having been exposed from an early age, I readily spent time where swearing was constant and creative, without feeling a sense of discomfort, except when it was used maliciously to berate or to belittle another individual. José Limón, who conducted fieldwork in South Texas, in communities dependent on agricultural labor, took the issue of swearing rather seriously and concluded that "swearing" (scatology) was a response to oppressive social conditions [12].

\section{Drugs}

Discussion of drug use as well as dealing drugs gradually increases over time across the four studies and receives extensive treatment in the most recent research by Bourgois. Whyte suggests that dope dealing was rare in the field setting; through his portrayal of the street-corner, dealing and using appear to be non-existent among main informants. Liebow by his descriptions implies that drug use existed outside his study network, and Anderson by his descriptions implies that drug use existed at the periphery of his study network. Bourgois opens his ethnography by a stark descrip- 
tion of the pervasiveness of drugs in the local area where he was living, including the residue evidence often discarded in the street. He is clear that most informants used drugs of one type or another, which were usually cocaine and alcohol. Some also sold drugs, especially crack-cocaine. The one time that he was offered marijuana, he refused.

The focus of my field research expanded from HIV/AIDS in labor camps of the Midwest to include drugs and alcohol when I moved to the southeastern United States. I came to spend considerable time in field sites in more than one state where drugs were sold and used. Although I was asked in several places if I had used drugs in the past (no one asked if I was a current user), it became clear that nearly everyone (men as well as women) desired my presence, similar to the disclosures of each of the four mentioned researchers, as an example of someone who did not use or sell drugs. Although several studies of alcohol use exist among agricultural workers [13-17], studies of drug use began to appear in the middle and late 1990s [18-23].

\section{E. Alcohol}

Each researcher handles differently the portrayal of alcohol in their research setting, where its inclusion in the text increases over time. Each of the four describes at least one instance of being present when primary study participants were drinking. Whyte mentions drinking with informants once and states in the appendix that he drank wine in the evening or at meals with the family where he ate. Liebow rarely refers to local drinking in the text; if informants are drinking, however, he is drinking. Anderson refers to times that he shares, drinks and buys alcohol inside or outside Jelly's as well as drinks inside informant apartments. The first references to alcoholic effects appear in Anderson, such as "reddened eyes, "nod out" and the like. To this time, it was sufficient to mention that "drinking" occurred without describing consequences. Bourgois refers often in reported speech to those times that he drank with informants, where he shares the bottle and "swigs," as they too are drinking. Some passages describe men as they were sniffing cocaine and "feeding" each other (administering drugs to another individual). His first contact with an informant (main contact, Primo), he refers to drinking outside the Game Room. Interestingly, each researcher is specific in describing what they and informants (virtually all men) consumed by quantity (can, bottle, pint) and by type or brand name: for Whyte this was wine and beer; for Liebow this was bourbon, gin and tonic, scotch and water, and beer such as Bud and Schlitz; for Anderson this was Heineken, Budweiser, Private Stocks and Old English Malt; and for Bourgois, the most consumed beverage was a local favorite, Bacardi.

Similar to my growing awareness that people expected that I would not use drugs, I heard comments of appreciation that I did not drink either on-site while conducting field research or off-site with friends or family. These encounters with local people gave me an opportunity to briefly report, without celebratory elaboration, that I did not drink, and that I had not drank for some time. I was willing to make the effort in my private life; it was no hardship to eliminate the occasional drink I might have at an occasional party of friends and/or co-workers. Whatever the level of drinking I experienced while younger it was inconsequential to those with whom I spent time in the field. People were more interested in the current stage of life that I was experiencing, while I was in the field, spending time with them.

\section{F. Dating}

References across the four studies to dating local women is non-existent except for the earliest study, by Whyte, where he describes the time that he took a local woman to a local dance, and Liebow who mentions a non-dating rule he had while conducting fieldwork. Whyte later in his monograph mentions that he married his girlfriend from the university they attended and describes the apartment where they lived in the field site. Although Bourgois and Anderson are each silent on whether they dated local women, it is unlikely. Anderson rarely mentions any contact with women in the field site. Bourgois was married at the time he entered the field; he and his wife lived in an apartment in the local neighborhood, where they were raising a young pre-school son while in the field site.

I was married at the time of all my field experiences with farm workers. When asked, I would tell people that I was married. Most soon learned my marital status. Three or four times a few men joked whether I might want to have sex with someone locally, invariably when women who provided commercial sexual services were visibly (but not audibly) in the vicinity; the topic was mentioned once without persisting. People were not expecting my involvement in any form of relationship while in the field. Women with whom I worked while conducting field research on commercial sex work each knew that I was married. Occasionally to introduce me to another sex worker, my local contact might mention "he is not dating," which was meant to say that I was not a potential customer.

In sum, across the four monographs that I reviewed, the most evident shifts in research style were changes in gender role identity of the author from the late 1930s to early 1990s, increased discussion of alcohol and drug use, and more attention to the process of the field experience.

(a) Increasing demonstration of respect toward women in the field: The two earliest researchers reportedly joined local men in women-watching (Whyte, Liebow) whereas the most recent two lack commentary on women-watching (Anderson, Bougois). Notably, the earliest monograph includes comments on the importance of removing a hat indoors (Whyte), and the most recent includes criticism of misogyny and sexual violence, and shows a photograph of the author in a baseball cap in the street (Bourgois).

(b) Varied description of participation in competitive sports or physical activity with only brief mention in the first (Whyte) and third monograph (Anderson), but nothing from the other two researchers.

(c) Shift from sanitized text in relation to swearing from Whyte (neither fieldworker nor primary informants cursed in the text) to selective cursing in reported speech of a few informants (but not fieldworker) to occasional cursing by informants and the fieldworker (Anderson) to ongoing cursing by both in the recent monograph (Bourgois). 
(d) Increasing emphasis on drinking with main informants: Whyte self-references himself once, several chapters into book, and in the appendix; Liebow has brief references to drinking in the text and elaborates his own involvement in the appendix. Anderson describes sharing, buying and drinking ("swigs") inside and outside Jelly's and inside men's apartments where he went to visit occasionally. Bourgois describes personal participation in drinking more than the other field researchers.

(e) Increasing textual references to illicit drug use: those who use and/or deal drugs become primary informants in the most recent study. Whyte is silent except for a brief comment that dope dealing was rare in Cornerville, and Liebow mentions no one through a fictive name or pronoun. Anderson implies that drugs were used through euphemisms (e.g., "good herb") and by attributions of personal effects (e.g., "nodding out" and "high"), and he once mentions a dealer by fictive name (Cochise) that sometimes spent time with the men at Jelly's. Bourgois describes ostentatious behavior that accompanies reported speech of primary informants (e.g., "sniffing," "drinking" and "feeding").

(f) Although each author demonstrates varied skills in conducting field research, these usually are implied through telling the reader how they managed to surmount a particular impasse or difficult situation. Selfreflexivity increases in the recent texts as the field researcher illustrates, by example, how he came to be immersed in the field setting.

\section{THE PROCESS OF ETHNOGRAPHY}

Next I describe the fieldworker's awareness of how people perceived him and how they felt a sense of belonging to the community where the study was being conducted. Three of the four describe a specific incident or single instance where they recognized their placement in the local community. Each uses the local language of the community, which strengthens the integrity of their conclusion that they were accepted by local people. Whyte came to perceive himself as a "friend" of the street-corner men. For him recognition came with his game-winning base hit at a baseball game that gave him "a wonderful feeling to come through when they were counting on me, and it made me feel still more that I belonged on Norton Street" [3: pages 306-307]. This occurred the first spring in the field site, thus 6-8 months into fieldwork. Liebow describes how one man, in his presence, said "he [is] okay" and notes later in the text how others described him as "up-tight" with Tally. He describes "that minimum sense of 'belonging' which alone permits an ease of manner and mind so essential in building personal relationships" [4: pages 239-242]. He writes "most people seemed to be taking it for granted that I belonged in the area" [4: page 247]. This took place in April, thus four months into his study. Anderson repeats some things he heard about himself. He writes that he felt that he went from "friend" and "stud" (stated by his primary informant, Herman), which gradually led to his "going for cousins" (stated by others as a sign for inter-personal closeness). He says this recognition came when Herman began to call him "my cousin" after they attended a local Christmas party [5: pages 14-22]. This was four to six weeks after he met Herman, which was four weeks into his project. Like the previous two, Bourgois reports things he heard, "You're good people," in recognition of his acceptance within the community. The key recognition point came for him when Primo referred to him with the strongest local language: "I remember the night when I first graduated to 'honorary nigga' status..." [6: pages 41-42] which most likely was very early in the second year of fieldwork.

Bourgois utilizes the gambit of revealing layers in the process of developing relationships with local people, unlike the previous fieldworkers that make it seem like establishing rapport is little more than surmounting a one-time hurdle. $\mathrm{He}$ discloses that he lack confidence in speaking with the women, except his apartment neighbor, Candy: "I did not have the same kinds of long-term relationships with [women] to allow for [matched] detail and confidence of a meaningfully contextualized life-history interview or conversation" [6: page 207]. Later, he worked with a female anthropologist in collaborating with local women. Bourgois used the unusual strategy of taking informants to prior sites of important events in their lives, such as a playground to recall school experiences. Near the end of his stay, when he shared the manuscript of his project with several informants, one told him: "You make us sound like such sensitive crack dealers."

My entry into the field came the first week of employment at the university, since I was specifically hired to direct the four-year HIV/AIDS research-education project. I accompanied the two principal investigators to a community meeting that first week, where I met town leaders and local service providers. The drive was two hours from the university to the farming town. I returned that weekend with one of the co-principal investigators who introduced me to the local staff and clients already enrolled in the study. That first night, after completing client interviews from a mobile camper next to the clinic, I walked down the main street of town as a form of the field technique of walkabout. Two weeks later I moved to the farming town, where I stayed three weeks with a staff member, before renting a small trailer behind the house of a man whom I met through a contact at the post office; he alone among members of his family spoke no English. Six weeks later I began ethnographic research in a concentrated area where men and women waited in the morning for rides to the fields or packing plants. One participant whom I met that first weekend shouted my name, as she walked over to talk with me, and another client later stopped to talk with me about an experience that he had witnessed the night before. Both encounters were visibly observed by people sitting-standing-lounging around the area, and these first two hours gave me "credentials" to spend time in the four-block staging area.

A year later I rented an apartment in an adjoining community, when my wife moved to the Southeast, where I resided the remaining five years of my long-term ethnography, which also included frequent travel of several days to several weeks. I used recommended contacts to gain entry for the four-year research-education project into the county corrections system, where a few clients occasionally spent time. I later contacted this same corrections officer to gain access to 
county inmates to conduct taped interviews with women and men whom I already knew.

Five months into my lone-investigator project, I contacted a migrant clinic in another state to make arrangements to interview clients of a residential drug treatment program for men with agricultural experience. A few days later I made my first trip to the clinic, nearly twelve hours by automobile from the home-base community. That visit, after meeting the staff and conducting interviews with participants, I was also introduced to graduates of the program. On my second trip, five weeks later, responding to a question I mentioned that I slept in my car (rental vehicle). A program graduate offered me accommodations in one of two cooperative-rented houses where they lived, which I continued each time that I visited for the remainder of fourteen months that I was collecting life stories at the treatment program. These men provided additional contacts for interviews with migrants who had moved into or were passing through the area.

Thus, my field experience over six years of long-term ethnography was first facilitated by institutional ties through the university, which later were supplemented by personal contacts that I made while living in the farming community and referrals from men and women in this town as well as those encountered in my travels. As I began to accumulate data on rural places where the men and women worked and/or lived, I could sound "knowledgeable" which permitted me to ask specific questions on a particular locale, when time permitted longer conversations with migrant workers whom I had recently met.

\section{METHODS}

I conducted intensive fieldwork for 42 months, team research for 32 months, and travel-work study over four months (two summers) during the 75 months that I lived in the southern United States. Some fieldwork overlapped with the team research when I was directing the four-year university study. Eighteen of 32 months in team research, for example, included sporadic fieldwork. Active field research took place once over 12 months, and four other active periods were 9 to 11 months of continuing fieldwork. The 14 months not counted for any research rarely stretched to two months. During this time I often visited a field site once or twice, so I was never truly outside the long-term ethnography. Final months of the team project overlapped time (some epidemiology, some continuing ethnography) as I began the independent field research. Thus, I was actively engaged in continuous "research" for one or the other, as well as for a combination of team research and independent investigation.

I had six primary ethnographic observation sites in three states: (a-b) two shape-up and day-haul staging areas seven hours apart, (c) commercial sex-work stroll in small agricultural city two-and-a-half and six hours from each staging area, respectively, (d) game room at a multi-service commercial unit and occasional staging area seven hours from the next nearest site, (e) cooperative housing for men in recovery and occasional visitors six hours from next nearest site, and (f) residential treatment center 30 minutes from the housing residence. There were 14 brief-contact sites across the three states plus two additional states where I visited labor camps, billiard rooms, staging areas, county jail and town stockade, emergency shelter, farmer's market, as well as casual contacts in eight additional states along the East Coast. By serendipity, I re-connected with 13 men across the three main sites, each of which were several hours apart by automobile driving distance, and with six men between home-base and one or another of the brief-contact or casual sites, also several hours apart. Occasionally I heard stories from strangers or new contacts in one site about some worker of notoriety ("popular icon") whom I previously met in another site. These contacts and stories demonstrated some aspects of an Imagined Community, whereby individuals may never meet everyone, face-to-face, but recognize their commonalities [24]. Re-contacts among agricultural workers take place and become the means whereby friendships are renewed, recent news and information are circulated, and prospects for improved employment are shared [25-27].

In the home-base, I conducted six field studies: (1) Contacts between agricultural workers and local townspeople, 10 months, (2) Incipient networks in time/space, 13 months, (3) Barroom activity, 11 months, (4) Street clusters, 16 months, (5) Worker barracks, 7 months, and (6) Local emergency shelter, 3 months (Fig. 1). I relied on 25 individuals as tutors throughout the overall period of long-term ethnographic research. Ten were sources of information on aspects of farm labor or commercial sex work; two for night and five for day observations were instrumental in providing advice on the street; and five assisted with the four-year study beyond enrollment. I prefer the term "tutor," given a willingness to share in expertise and knowledge, rather than the common term "informant," which I incorporated in earlier passages (above) for ease of reading comprehension. Both the Migrant Worker Risk Study and the Farm Worker Drug Onset Study provided combined verbal and written consent, and secured respondent signatures on the form. Each project was reviewed by the institutional review board at the University of Miami School of Medicine (USA).

\section{SAMPLE}

The sample for my life story interviews comprised a total of 143 unduplicated men and women who were current drug users or had been active users in the recent past. All but three men and 13 women of these 143 were working in agriculture or had performed farm labor at the time of interview [anticipating later narrative research, my first year in the homebase I taped 17 preliminary interviews with twelve individuals at the local homeless shelter not counted above]. A few respondents worked in packing plants but had never performed field work in agriculture. Thus, the core sample for most my published analyses were 127 men and women who had basic experience both in agriculture and in drug use. Most were working or had worked in the fields, usually at harvest or planting time, and they had migrated outside a home state or county and/or they had performed local seasonal work. For the present analysis, I compare these two samples that basically were the same across essential characteristics.

Of these 127 persons, 46 were born outside the United States (transnational) and 81 were born in the United States. Comprising 101 men and 26 women, they were interviewed at ten sites in five locales in three states of the southeastern United States. Since several were interviewed more than 
Drugs/AIDS Intervention among Migrant Workers (Risk Behavior Survey \& Follow -Up; and Fieldwork)

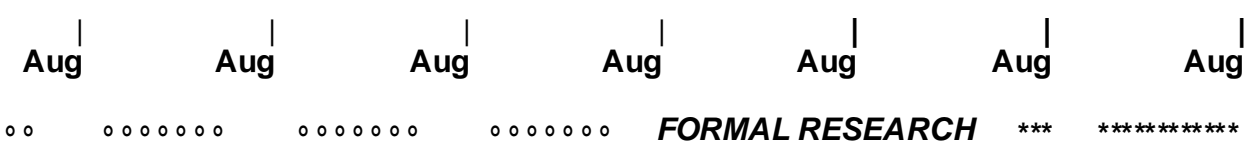

$3 \mathrm{~m}$ $8 \mathrm{~m}$

$$
\overline{2 m}
$$

Street Clusters

Street Networks

Bar Behavior

Barracks

\section{LOWER SOUTH: Clusters}

(Life Story Interviews and Fieldwork)
Inscription in Farm Worker Drug Use

Keith V. Bletzer

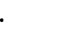


81.8 percent reported it was the first that they ever used, and the rest reported it was the second (18.2\%). Ninety-eight persons reported that marijuana was the first or second drug they had ever used (87.6\%); 76.4 percent reported that it was the second drug they ever used, and the rest reported it was the first $(23.6 \%)$. Crack-cocaine, the drug ranking third by the number of lifetime users, generally was later in its onset; 69.8 percent reported it was the third, fourth or fifth substance they used, whereas only 9.4 percent reported it was the first or the second drug. Nine persons reported they first used crack-cocaine after prior experience with seven to twelve other drugs. Drugs of early onset overwhelmingly were those initiated in hometowns or in places of relocated residence during adolescence [18].

Most drug use onset occurred when a person was living in their natal community, where they were born $(51.9 \%)$, or the second, third or fourth community to which their parents moved while they were still young (minors under age 18) or, for themselves, community or communities that later in life became home-base (36.0\%). Very few cases were reported in which individuals initiated a new drug in a situation that was of an indeterminate temporary duration (e.g., seasonal residence in a camp; return to visit family in a home country or another state; military furlough) or some activity with a known termination date (e.g., incarceration in county jail [typically few months]; or contract to work in a mining operation outside one's home country), or a short time after one has begun to reside in a new community. Most the onset of new drugs took place after residence of 12 months or more in a locale. Thus, most onset occurred in "a place of familiarity" (454/525 or $86.4 \%$ ) with little occurring in "a place of sojourn" (71/525 or $13.5 \%)$ (Fig. 2).
As it was, the initiation of a new drug rarely occurred soon after settling into a new community. Onset two weeks after a residential move was the earliest instance in the sample. Short-term initiation on a return visit to family or hometown after a few years as a migrant was common among the scenarios for initiation in a "place of sojourn" (43/71 or $60.6 \%$ ). Situations that were rare among "places of sojourn" included such activities as seasonal work (e.g., farm labor or rodeo) (17/71 or $23.9 \%)$, driving a truck long-distance or a brief period spent out-of-town with a work crew (each 4/71 or $5.6 \%$ ). What was surprising was that the most common experience of many farm workers, that of seasonal residence in a labor camp from a few weeks to several months year after year, yields cases of reported onset no more than 13 times among "places of sojourn" (13/71 or 18.3\%). This is low $(13 / 525$ or $2.5 \%$ ) among initiation situations (drug use onset) in which workers participate in seasonal travel rather frequently over a lifetime. Interestingly, no more than four cases of drug initiation took place in an agricultural setting such as a packing plant (one on lunch hour; one at another time) $(0.8 \%)$ or field setting such as an orchard (two in a citrus grove) $(0.4 \%)$, both of which are common settings for farm workers in the southeastern United States. There were no cases of initiation on visits that sampled workers made to a nearby town or community while working "on the season."

A review of the total 589 substances reported for lifetime use by 143 individuals in the full sample revealed that nearly one-third were initiated before age 15 (172/589 or $29.2 \%)$, and more than one-half before they were 18 (306/589 or $51.9 \%)$ and $21(364 / 589$ or $61.7 \%)$. By far, the largest cluster by age range was for those aged 14 to 18 , as reported by 35 or more persons $(228 / 589$ or $38.7 \%)$ for each year, and 14 and 15 , reported by more than 50 individuals (106/589 or

\section{Place-Bonding and Drug Use Onset} Trans-Migrant and US -Born Agricultural Workers

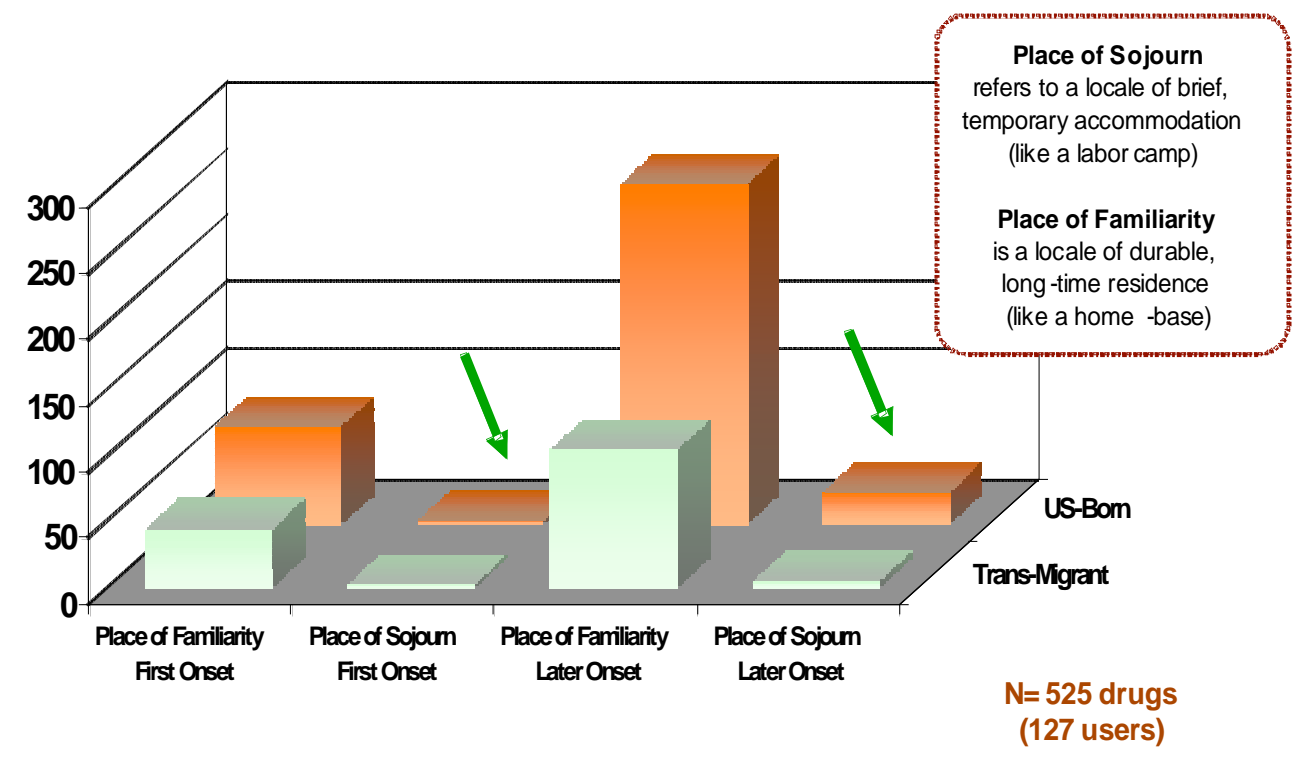

Unpublished data: "Inscription in Substance Use among Farm Workers

Fig. (2). One-third to two-thirds of the annual work of agricultural workers occurs "on the season" but only 5.3 to 7.1 percent of new and later onset of drug and alcohol use takes place in a Place of Sojourn, respectively. 
$18.0 \%$ ) for each year. The next highest cluster was ages 1213 and 21-24, reported by 22 and 26 individuals, respectively. Remaining ages were reported by less than 20 individuals for each successive year. Interestingly, the onset of new drugs continued among some men and women entering young adulthood. Sixty-three persons continued to initiate at age 30 or older $(63 / 143$ or $44.0 \%)$. Mean age of onset for first drug ever was similar for men (13.63) and women (13.77).

Considering that sampled men and women represented a range of ages (mean sample age was 38.6; median was 38), the mean age of first onset is comparable to reports in the literature on adolescent practices [31-42]. Typically these studies draw samples from younger populations for calculating onset. Seventy-five percent of those in my samples in contrast were age $43 /$ under and $25 \%$ were age 32 /under. For this reason I was able to calculate a mean age for most recent onset ("final drug") which serves as an indicator of initiation of new drugs into one's repertoire, which can be placed into perspective by considering those identified drugs that are "currently used."

Few differences were evident in onset by number of years in agricultural employment. Mean age of onset fell 1.5 years for those with more than 25 years of experience in farm labor (14.76), less than five years of experience (13.39) and those between five and 25 years of prior experience in agriculture (13.21) (Fig. 3). The more years that a person reported that they were active in agriculture, the more likely that an individual would report a lower amount of lifetime use: high of 4.06 drugs in their lifetime for those with less than five years in agriculture, versus a low of 3.76 drugs for those who had more than 25 years of farm labor experience. Similarly, the more experienced farm workers reported greater mean age of onset for the last drug they initiated five years older than those with less than five years of experience in farm labor (age 28.57 onset of last drug for those with more than 25 years versus age 23.52 onset of last drug for those less than five years experience in agriculture). Most of this is due to the older mean age of those with more than 25 years experience at the time of their interview (mean 47.14) versus those with less than five years experience in farm labor (mean 36.65). Despite an expected difference across the sample, nonetheless, a continuing inclination to initiate new drugs into early and middle 20 s is reflective of social pressures [15, 43] and accompanying lifestyle hardships to which agricultural workers are exposed [13, 14, 19-21, 25$27,44]$. Residential relocation and migratory movement are considered the greater hardships, as men and women mix and match stationary and shifting residence (anchor households, re-location, respectively), and rotating arrangements (shifts in kin composition), in their pursuit of economic livelihood.

Current users reported a greater mean number of drugs used in their lifetime (4.29) versus those in treatment (3.76) and those in recovery (3.01). Although the mean age of onset of the first drug was within eight months for men and women across all three groups, mean onset age for the last drug, understandably, was different. From a high of 27.2 years for current users to a low of 20.1 years for those in recovery and 24.7 for those in treatment, range of years for the last drug initiated was greater than that for any category, except ethnicity and national origin.

Influence of origin, lifestyle and background on age of onset was most noticeable for those born in the United States versus those born outside this country (Fig. 4). U.S.-born women and men had a higher mean age of onset for last drug initiated (27.3) than those born outside this country (21.9). Mean age of the sample does not affect this difference, since those born outside this country were similar in age (mean 38.2) to those born within the United States (mean 38.8).

\section{Onset: First Drug, Final Drug By Years Experience in Farm Labor}

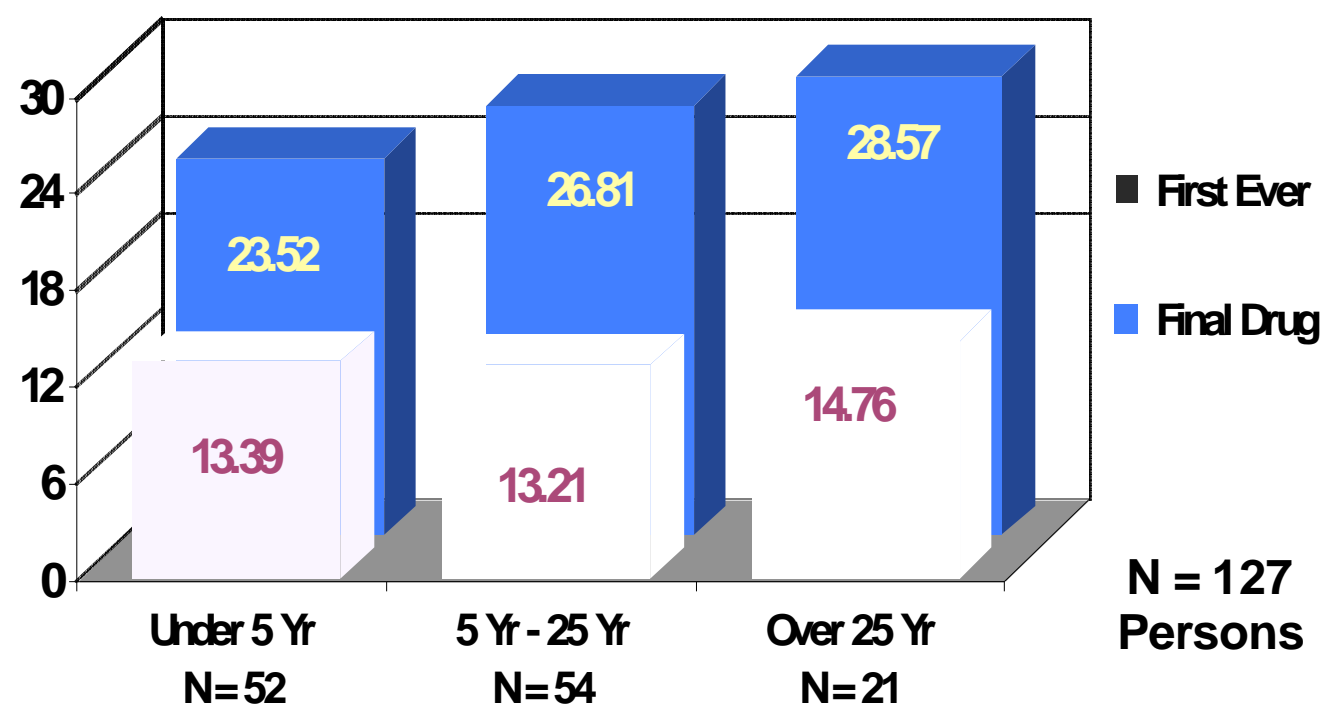

Fig. (3). 
Those born in the United States varied in mean age of onset of first drug used and last initiated. These data on first drug and last drug initiated provide evidence for a continuing process of new drug experimentation that reflects the often precarious situation of agricultural workers, at the same time that it represents the sometimes distorted efforts to take control and to find a remedy for the unpleasant experiences and personal hardships that one encounters in agricultural labor.

\section{Onset: First Drug, Final Drug Trans-Migrant and US -Born Compared}

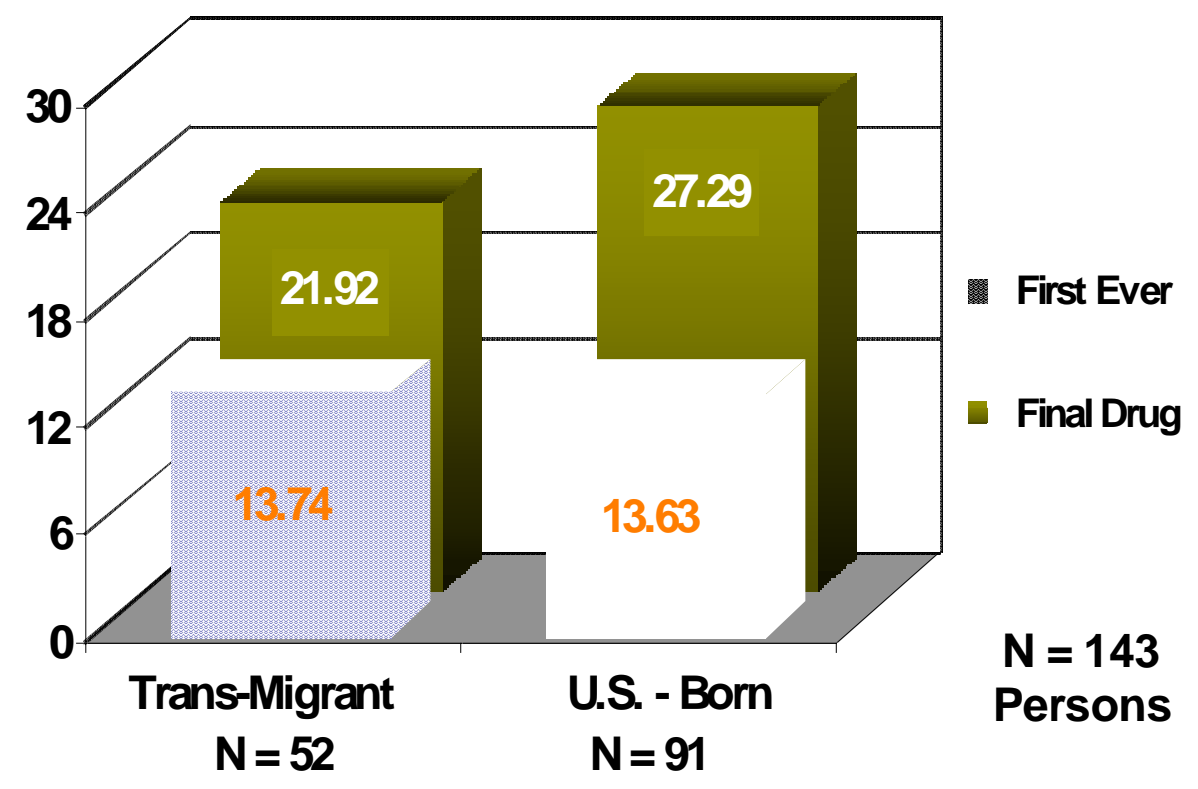

Fig. (4).

\section{Drug Use Onset in Selected Populations}

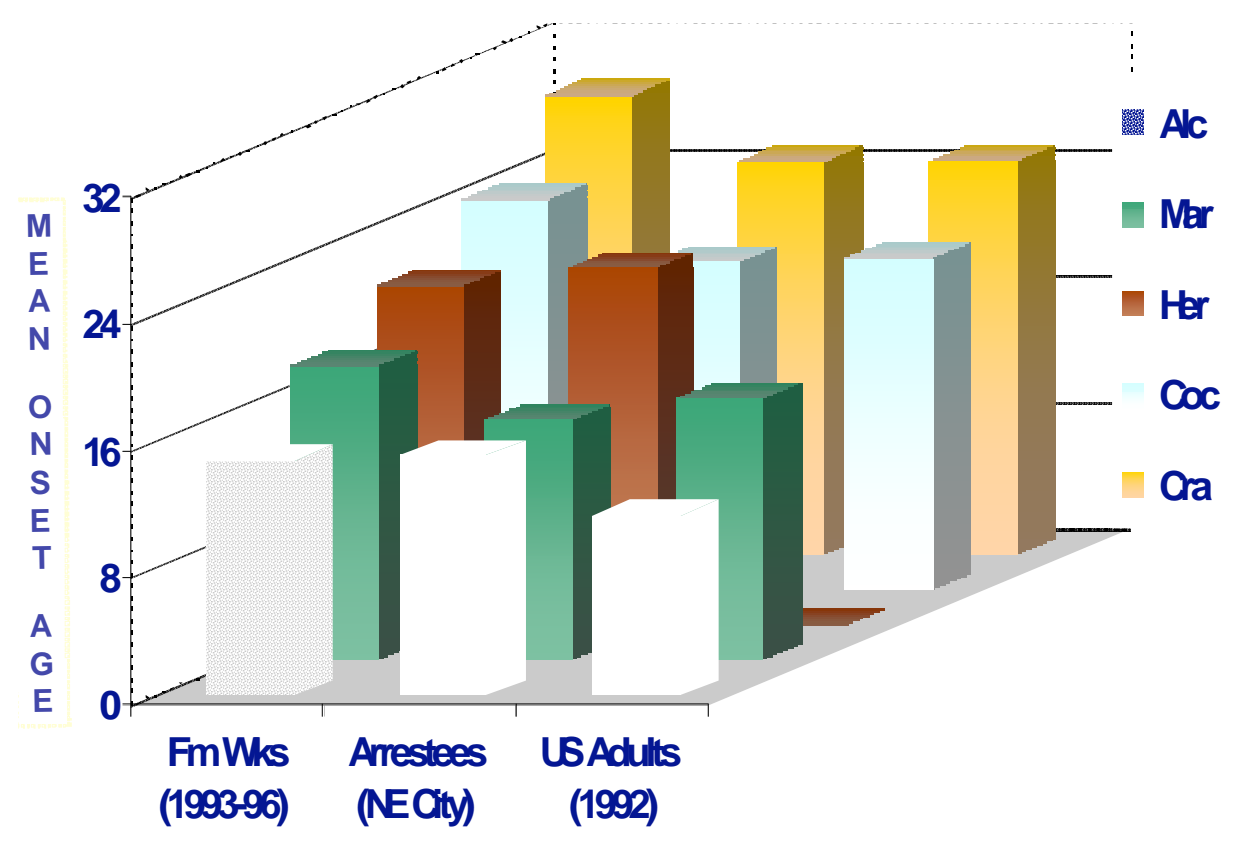

Fig. (5). The Migrant Worker Risk Study was based on a four-year sample of 981 male and female "farm workers" who were working (or once worked) in agriculture and currently used hard drugs [22, 23]. The Drug Abuse Monitoring Program yielded drug use data on 1,262 booked inmates, who had been in custody no more than 48 hours in a large northeastern metropolis, which was one of 35 cities participating in the assessment [49]. The Longitudinal Youth Survey was based on a national cohort of 12,686 teenagers that formed a panel survey of young men and women, first interviewed in 1979, and re-interviewed when they reached their late 20s in 1990 and 1992 [50]. 


\section{SUMMARY AND CONCLUSION}

Agricultural workers are said to bear greater burdens in employment and residence [9, 10, 25-27, 45, 46] and they experience high levels of troublesome and dangerous experiences $[19,20,26,27,45]$ that are conducive to increased drug/alcohol use more than other populations (Fig. 5). This does not mean that all agricultural workers within the United States use drugs but it does highlight the risk to drug use experienced by those employed in agriculture [13-23]. Even though many farm workers do not use "drugs," the ratio of alcohol consumption to drug use is relatively high, which is similar to a high proportion within the general population that currently consumes or has consumed alcohol at some point in their lifetime, with lower levels of prior or current use of illicit drugs [47].

To effectively meet the needs of this continually reconstituting community requires solid research with an edge to validity within specific locales. The collection of reliable data that are collected in this fashion across both time and space will enable development of comprehensive strategies of delivering the services that are most needed by agricultural workers [48].

\section{ACKNOWLEDGEMENTS}

Special thanks to all the men and women who over the years contributed to participatory field research. Funding is graciously acknowledged from a Faculty Grant-in-Aid from the College of Liberal Arts and Sciences, and National Research Service Award, Department of Anthropology, Arizona State University; Wenner-Gren Foundation for Anthropological Research ("Inscription in Drug Use among Farmworkers," Keith V. Bletzer, Principal Investigator); National Institute on Drug Abuse ("Drugs/AIDS Intervention among Migrant Workers," Norman L. Weatherby, Principal Investigator).

\section{REFERENCES}

[1] Coffey A. The ethnographic self: fieldwork and the representation of identity. Thousand Oaks: Sage Publications 1999.

[2] Sanjek R, Ed. Field notes: the makings of anthropology. Ithaca: Cornell University Press 1990.

[3] Whyte WF. Street corner society: the social structure of an Italian slum. Fourth Ed. Chicago: University of Chicago Press 1993. (First published 1943)

[4] Liebow E. Tally's corner: a study of Negro street corner men. Boston, MA: Little, Brown 1967.

[5] Anderson E. A place on the corner: a study of Black street corner men. Second Ed. Chicago: University of Chicago Press 2003. (First published 1978)

[6] Bourgois P. In search of respect: selling crack in El Barrio. Second Ed. Cambridge/New York: Cambridge University Press 2003. (First published 1995)

[7] Agar M. The professional stranger: an informal introduction to ethnography. Second Ed. San Diego, CA: Academic Press 1996. (First published 1980)

[8] Freilich M, Ed. Marginal natives at work: anthropologists in the field. Cambridge: Schenkman Publishing Company 1977.

[9] Wells M. Strawberry fields: politics, class, and work in California agriculture. Ithaca, NY: Cornell University Press 1996.

[10] Friedland WH, Nelkin D. Migrant agricultural workers in America's Northeast. New York: Holt, Rinehart and Winston 1971.

[11] Heppel ML. Harvesting the crops of others: migrant farm labor on the eastern shore of Virginia. PhD [dissertation] Department of Anthropology, American University 1982.

[12] Limón J. "Carne, carnales," and the carnivalesque: Bakhtinian "batos," disorder, and narrative discourses. Amer Ethnologist 1989; 16(3):471-486.
Duke MR, Gomez Carpinteiro FJ. The effects of problem drinking and sexual risk among Mexican migrant workers on their community of origin. Hum Organ 2009; 68(3): 328-39.

[14] Morales R. Drinking patterns among seasonal agricultural workers, $\mathrm{PhD}$ [dissertation]. Syracuse (NY). Syracuse University 1985.

[15] Trotter RT II. Mexican American experience with alcohol: South Texas examples. In: Bennett LA, Ames GM, Eds. The American experience with alcohol: contrasting cultural perspectives, New York: Plenum Press 1985.

[16] Van Wilkinson W. Influence of lifestyles on the patterns and practices of alcohol use among South Texas Mexican Americans. Hispanic J Behav Sci 1989; 11: 354-65.

[17] Watson J, Mattera G, Morales R, Kunitz SJ, Lynch R. Alcohol use among migrant laborers in western New York. J Stud Alcohol 1985; 46: 403-11.

[18] Bletzer KV. Onset of substance use among transnational and domestic agricultural workers: social relations and place of initiation. Contemporary Drug Problems 2004; 31(1): 89-127.

[19] Bletzer KV. Open towns and manipulated indebtedness among agricultural workers in the New South. Amer Ethnologist 2004; 31(4): 530-51.

[20] Bletzer KV. Modulation of drug use in southern farming communities: social origins of poly-use. Hum Organ 2009; 68(3): 340-49.

[21] Bletzer KV, Weatherby N. Variation in drug use in southern farming communities: watermelon men in the rural South. Hum Organ 2009; 68(2): 115-28.

[22] Weatherby NL, McCoy HV, Bletzer KV, Forney MA, McCoy CB, Inciardi JA, McBride DC. Sexual activity and HIV infection among drug users: migrant workers and their sexual partners in south Florida. Fla J Public Health 1995; 7(1): 22-26.

[23] Weatherby NL, McCoy HV, Bletzer KV, et al. Immigration and HIV among migrant workers in rural southern Florida. J Drug Issues $1997 ; 27(1)$ : 155-72.

[24] Anderson B. Imagined communities: reflections on the origins and spread of nationalism. Revised ed. London/New York: Verso 2006. (First published 1983)

[25] Griffith D, Kissam E. Working poor: farm workers in the United States. Philadelphia: Temple University Press 1995.

[26] Martinez R. Crossing over: a Mexican family on the migrant trail. New York: Metropolitan Books 2001.

[27] Rothenberg D. With these hands: the hidden world of migrant farm workers today. Berkeley: University of California Press 1998.

[28] Kandel DB, Yamaguchi K, Chen K. States of progression in drug involvement from adolescence to adulthood: further evidence for the Gateway Theory. J Stud Alcohol 1992; 53: 447-57.

[29] Kandel DB, Raveis VH. Cessation of illicit drug use in young adulthood, Arch Gen Psychiatry 1989; 46: 109-16.

[30] Oetting ER, Donnermeyer JF, Deffenbacher JF. Primary socialization theory: the influence of the community on drug use and deviance, III. Subst Use Misuse 1998; 33: 1629-65.

[31] Baumeister SE, Tossmann P. Association between early onset of cigarette, alcohol and cannabis use and later drug use patterns: an analysis of a survey in European metropolises. Eur Addict Res 2005; 11(2): 92-98.

[32] Benjet C, Borges G, Medina-Mora ME, et al. Prevalence and sociodemographic correlates of drug use among adolescents: results from the Mexican Adolescent Mental Health Survey. Addiction 2007; 102(8): 1261-68.

[33] Clark DB, Jones BL, Wood DS, Cornelius JR. Substance use disorder trajectory classes: diachronic integration of onset age, severity, and course. Addict Behav 2006; 31: 995-1009.

[34] Dooley D, Prause JA, Ham-Rowbottom KA, Emptage N. Age of alcohol drinking onset: precursors and the mediation of alcohol disorder. J Child Adolesc Subst Use 2005; 15(2): 19-37.

[35] Galanter M. Alcohol problems in adolescents and young adults: epidemiology, neurobiology, prevention, and treatment. New York: Springer 2006.

[36] Lo CC. Timing of drinking initiation: a trend study predicting drug use among high school seniors. J Drug Issues 2000; 30(3): 525-54.

[37] Monshouwer K, Smit F, de Graaf R, van Os J, Vollebergh W. First cannabis use: does onset shift to younger ages? Addiction 2005; 100(7): 963-70.

[38] Novins DK, Beals J, Mitchell C. Sequences of substance use among American Indian adolescents. J Am Acad Child Adolesc Psychiatry 2001; 40(10): 1168-74. 
[39] Robins LN. The natural history of adolescent drug use. Am J Public Health 1984; 74: 656-57.

[40] Stryker LA, Duncan SC, Pickering MA. The social context of alcohol initiation among African American and White youth. J Ethn Subst Use 2003; 2(1): 35-42.

[41] Swadi H. A longitudinal perspective on adolescent substance use. Eur Child Adolesc Psychiatry 1992; 1: 156-70.

[42] Wagner EF, Lloyd DA, Gil AG. Racial/ethnic and gender differences in the incidence and onset age of DSM-IV alcohol use disorder symptoms among adolescents. J Stud Alcohol 2002; 63(5): 609-19.

[43] Brandes S. Staying sober in Mexico City. Austin: University of Texas Press 2002.

[44] Grzywacz JG, Quandt SA, Isom S, Arcury TA. Alcohol use among immigrant Latino farm workers in North Carolina. Am J Ind Med 2007; 50(8): 617-25.
[45] Sheridan LM. "I know it's dangerous": why Mexicans risk their lives to cross the border. Tucson, AZ: University of Arizona Press 2010.

[46] Du Bry T. Immigrants, settlers, and laborers: the socioeconomic transformation of a farming community. New York: LFB Scholarly Publishing LLC 2007.

[47] Substance Abuse and Mental Health Administration. Annual Household Drug Use Survey for 2008. Washington, DC: Government Printing Office 2009.

[48] Arcury TA, Quandt SA, Eds. Latino farmworkers in the eastern United States: health, safety and justice. New York: Springer Science+Business Media 2009.

[49] Kane RJ, Yacoubin GS. Patterns of drug escalation among Philadelphia arrestees: an assessment of the Gateway Theory. J Drug Issues 1999; 29: 107-20.

[50] Johnson TP, Mott JA. The reliability of self-reported age of onset of tobacco, alcohol and illicit drug use. Addiction 2009; 96: 118798.

(c) Keith V. Bletzer; Licensee Bentham Open.

This is an open access article licensed under the terms of the Creative Commons Attribution Non-Commercial License (http://creativecommons.org/licenses/by-nc/3.0/) which permits unrestricted, non-commercial use, distribution and reproduction in any medium, provided the work is properly cited. 